\title{
STRATEGIC IMPLEMENTATION OF AUTOMATED ONLINE SALES INFORMATION SYSTEM FOR SMALL AND MEDIUM ENTERPRISE'S (SME's) \\ (Case Study at Tiara Handicraft Surabaya)
}

Zakky Zamrudi

Riyadi

Devi Farah Azizah

\begin{abstract}
This research purposes are to give an alternative solution for the Small and Medium enterprises (SME's) to implement an ecommerce information system or also called as online sales information system. The alternative given by this research is by searching for a cheaper and easier alternative ecommerce implementation that easily controlled by the SME's itself. The system implementation was adopting the Stewart framework in system implementation. The research methodologies employed here was using a qualitative research by using case study approach at Tiara-Handicraft Surabaya. The result shows that the new system implementation will give a good direct impact against system control and cost control if the system implementation is carried out.
\end{abstract}

\section{Keywords: Prestashop, Implementation framework, front-office, back-office, installation}

\section{INTRODUCTION}

Small and medium enterprise's (SME's) today is become a fundamental subject for economic growth in a country. There is some reason why SME's become a main reason of economic growth in countries.

Partomo (2004) stated some advantage of SME's compared to large companies as follow:

1. Innovations in technology have easily happened in product development.

2. Familiar human relationships in small firms.

3. The ability creates enough employment opportunities for labor or absorption.

4. Flexibility and ability to adapt to changing market conditions quickly compared with large-scale enterprises in general bureaucratic.

5. The presence of dynamism managerial and entrepreneurial roles.

In Indonesia, SME's has support the economic growth continuously by its growth and contribution. Syarifudin Hasan in Tempo.com (2013) as a State Minister of Cooperatives and Small Medium Micro Enterprises stated that the contribution of SMEs to GDP by 56 percent and 97 percent of its contribution to employment. This is a fact that SME's has an important role in the state economic growth.

In order to increase the production and sales capacity of SME's most of them was used the new systems by using online systems. Today's trend among SME's is by selling their product through internet rather than using direct selling. Online selling is being regarded to increase the selling volume with low-cost promotion and distribution.

For today's Online-marketing-strategies, by promoting through social media only is not enough anymore. Today's customer are has a higher understanding towards the online business and ecommerce. The potential and educated customer needs deeper information about the product, company business profile. The limitation of social media is they only have several feature and application that fulfill the SME's needs to promote their business. . It doesn't mean that using social media as a promotion media would be used. Yet, it still used as a secondary promotion media that will be linked to the main personal website of SME's.

This personal website would be functioned as a sales information systems which is contain product catalog, company profile, the payment procedure, and user information that would not be published.

In adopting the information systems for SME's which is most of them didn't have a special division that handle the information systems, is a problem. By using an instant and user friendly ecommerce software, it is expected that this information systems are able to support SME in 
organizing and move to next stage of marketing strategies. From these problems this research is entitled as "STRATEGIC IMPLEMENTATION OF AUTOMATED ONLINE SALES INFORMATION SYSTEMS FOR SMALL AND MEDIUM ENTERPRISE'S (SME's)"

\section{THEORETICAL FRAMEWORK}

\section{A. Small and medium enterprises}

SME's definition has varies meaning around the world. SMEs are usually enterprises that employ no more than 250 employees. The technical definition varies from country to country in the Asia-Pacific region but is usually based on employment, assets, or a combination of the two (Kotelnikov, 2007:2).

Today's, most of firms are using technology and information system to help their business. Most of SME use third parties help to develop their system to reduce the cost, which is collaborate between the IT consultant and the SME's CEO (Levi and Powell, 2004:46). In adopting the information system there is several issues by Levi and Powell (2004:47) as follows:

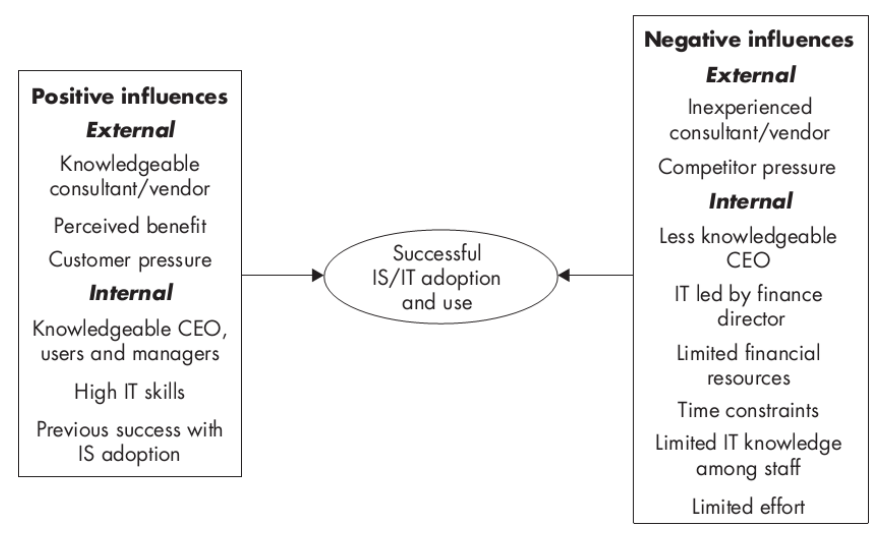

Figure 1: IS an adoption issue in SME's

Sources : Levi and Powell (2004:47)

SME's use the roles of technology to help them in running their business effectively and efficiently. There will several steps on how SME's will adopt the role of ICT based on their necessity.

\section{B. Strategic Implementation of Information System}

The strategy implementation is the sum total of the activities and choices required for the execution of a strategic plan. It is the process by which objectives, strategies, and policies are into action through the development of programs, budgets, and procedures. System implementation is one stage of The SDLC approach. SDLC assumes that the life of an IS starts with a need, followed by an assessment of the functions that a system must have to fulfill that need, and ends when the benefits of the system no longer outweigh its maintenance costs.

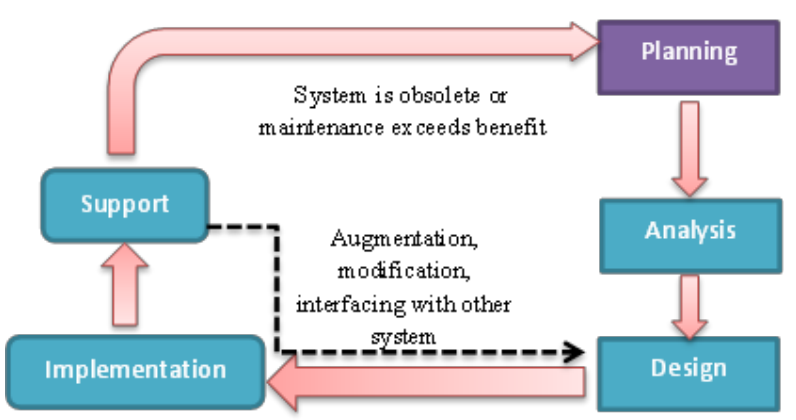

Figure 2 :System Development Life Cycles Source : : Oz (2008:415)

Before Information system is being implemented to the corporate, there is several step in implementing system. There are 6 steps in implementing system as follows (Stewart et. al 2002:682).

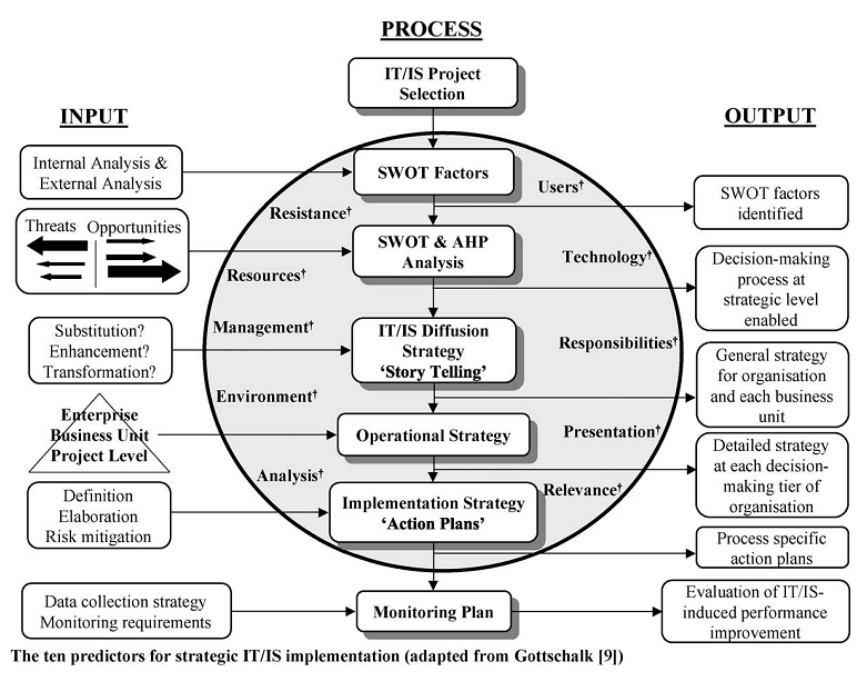

Figure 3 : Strategic is implementation framework

Source : Stewart et. al (2002:682)

1. SWOT factors: The system analyst is needed to undertake an external and internal analysis.

2. SWOT analysis: is a commonly used tool for analyzing internal and external environments in order to attain a systematic approach and support for a design situation.

3. IS diffusion strategy 'story telling': The data gathered from previous step, must be carefully analyzed, the recommendation must be reviewed by whole involved parties.

4. Operational strategy: From the IS diffusion strategy, the operational strategy is derived. The detailed operational 
performance and strategies were developed from previous story telling.

5. Implementation strategy 'action plans': The implementation strategy is the most detailed component of the proposed strategic IT/IS implementation framework.

6. Monitoring plan: The activity involved including performance measures and data collection strategies required for each IS project implemented by the organization.

\section{Automated Sales Information System}

Automated sales are sales generated with the use of electronic media to place, process, and schedule delivery of the goods and services ordered (Wisegeek, 2013).

There are customer relationship management (CRM), sales force automation (SFA), and the marketing automation.

Marketing automation is a category of software. It streamlines, automates, and measures marketing tasks and workflows. So companies like yours can increase operational efficiency and grow revenue faster (Miller, 2013:6).

SFA is the application of information technology to support the sales function (Ang \& Iriana, 2006:214). Thus, SFA is an integration of information and technology (hardware and software) that able to be used to help sales function works efficiently.

\section{Strategic Implementation of Automated Online Sales Information system}

The first step of system implementation is called as initiation step where there are 6 steps in implementing system as follows (Stewart et. al 2002:682). The steps are SWOT factors, SWOT analysis, IT diffusion strategy, Operational strategy, implementation strategy, and monitoring plan.

One of the most used online store software today Prestahop which provide many features such as Catalog, Orders, Customers, Price Rules, Shipping, Localization, Modules, Preferences, Advanced Parameters, Administration, and Stats. The more and better feature is available as a separated module that can be purchased directly from prestahop.com.

In creating a relationship between the customers, suppliers, and store, a Data flow diagrams (DFDs) reveal relationships among various components in a program or system

Prestahop provides two basic interfaces for its users, the Front office and Back-Office. Front office provides basic interfaces for user to check their chart and choose an expedition to deliver product. Back Office welcome page is made up of three different areas such as, navigation, dashboard, and prestashop live feed.

\section{RESEARCH METHOD}

This research will use qualitative method by using case study approach. Based on Astalin (2013:118) qualitative research is a systematic scientific inquiry which seeks to build a holistic, largely narrative, description to inform the researcher understands of a social or cultural phenomenon

In analyzing data there is several steps that well known to be done sequentially, though analyzing data is not always being done sequentially. In the reality, data analyzing has different treatment for every single research. Data analysis is not off-the-self; rather, it is custom built, revised and choreographed (Huberman\& Miles in Creswell 2007:150)

Creswell proposed data analysis called as Spiral Data Analysis as shown in figure 4. To analyze qualitative data, the researcher engages in the process of moving in analytic circles rather than using a fixed linear approach (Creswell 2007:150).

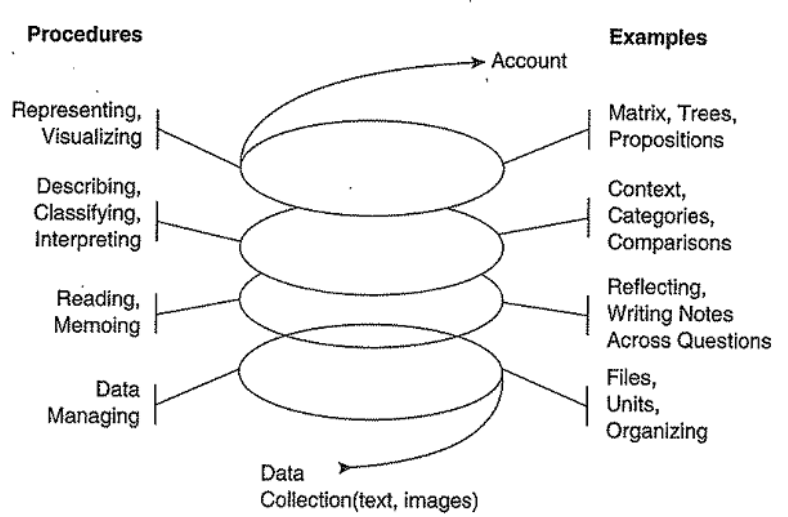

Figure 4 : Loop Data Analysis

Source : Creswell (2007:150)

1. First loop (Data Management): At this stage researcher organize data into file, indexing, or computer database.

2. Second loop (Reading, Memoing): In this step researcher try to read the transcript that already collected in whole database.

3. Third loop (Describing, Classifying, and Interpreting): In this process researcher try to develop the themes through some classification system that already build in the first stage and provide necessary 
information based on the problems formulation

4. Fourth loop (Representing, Visualizing): In the last stage researcher present the data into necessary information that can be well understood by readers.

\section{RESULT AND DISCUSSION}

\section{A. DESCRIPTION SECTION}

Tiara Handicraft was established in 1995 and it is just a hobby in the beginning. Start From a hobby to recycle unused goods and another hobby related with cloth material, Mrs. Titik start to combine those materials.

Along with the evolvement of production capacity, Tiara is focus on producing:

1) Gifts for newly born babies and other things for babies.

2) Household, such as curtain, table clothes, pillows, bed sheets, etc.

3) Wedding accessories (souvenirs, bedroom ornaments, ceremony equipment etc.)

4) Handbags

5) Clothes for children and adults

In Tiara Handicraft the total amount of members is 35 people in which 21 of them is under the training which is most of them is disability people.

The organizational structure in Tiara Handicraft is consisting of one general manager, one creative director which is directly under the general manager supervision. There are four divisional structure in which consists of operational, financial, marketing, and also the material handling and shipping.

\section{B. DATA REDUCTION}

Tiara Handicraft sales activity is included into directs selling. Direct selling is a marketing and transaction activity with consumer directly to the consumer.

From the figure above it is explained that there is two customers that Tiara handled. The retail customer is ordinary customer that only would buy the available product in show room or in website.

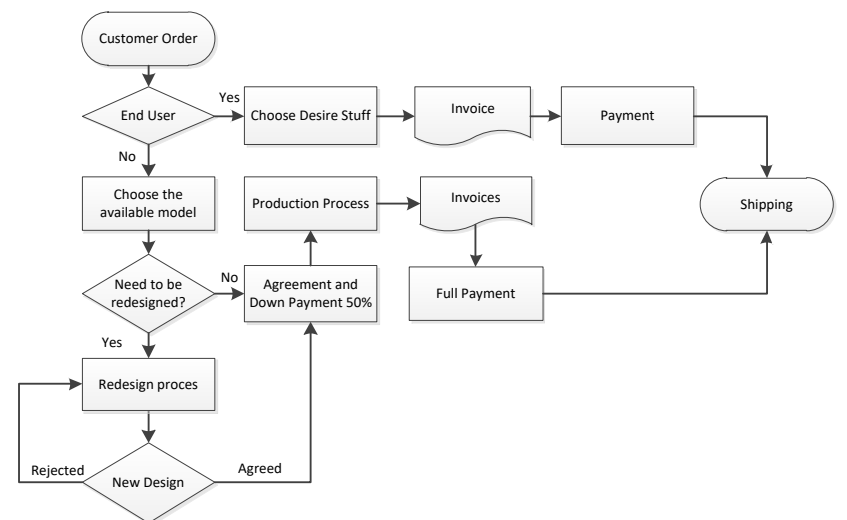

Figure 5: Tiara handicraft selling procedure Source : Tiara Handicraft, 2014

Tiara handicraft also has its own websites addressed www.tiara-handicraft.com. This is established in order to promote them via internet media. This existing website is categorized as a content management software (CMS) in which is not suitable with the Tiara handicraft needs towards the telemarketing activity and also ecommerce activity.

Basically this website is consisting of two parts. There are the user page and the admin page. The user page is a main page where the domain page is set, in this case www.tiara-handicraft.com will direct to user main page. While at the admin page, there are several features to manage websites content. As shown at the picture below:

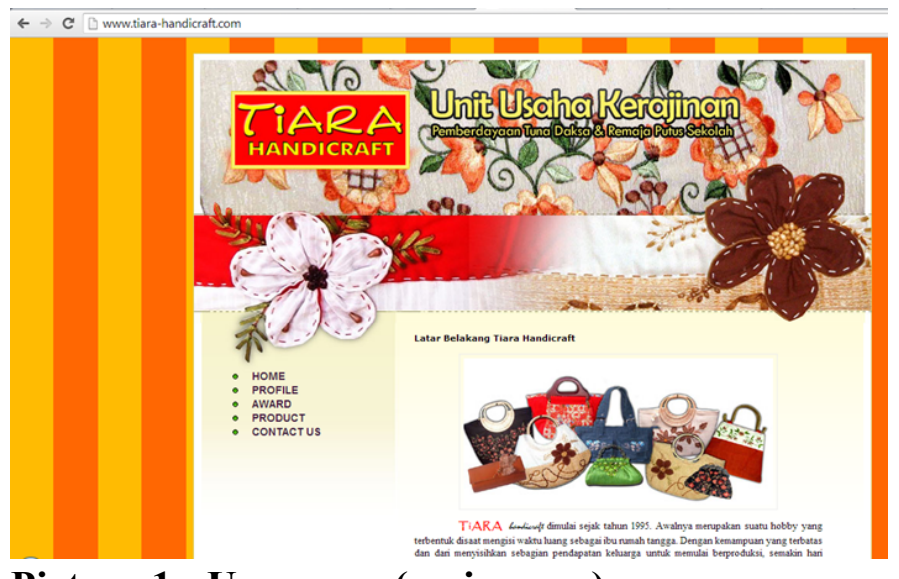

Picture 1 : User page (main page)

Source : www.tiara-handicraft.com 


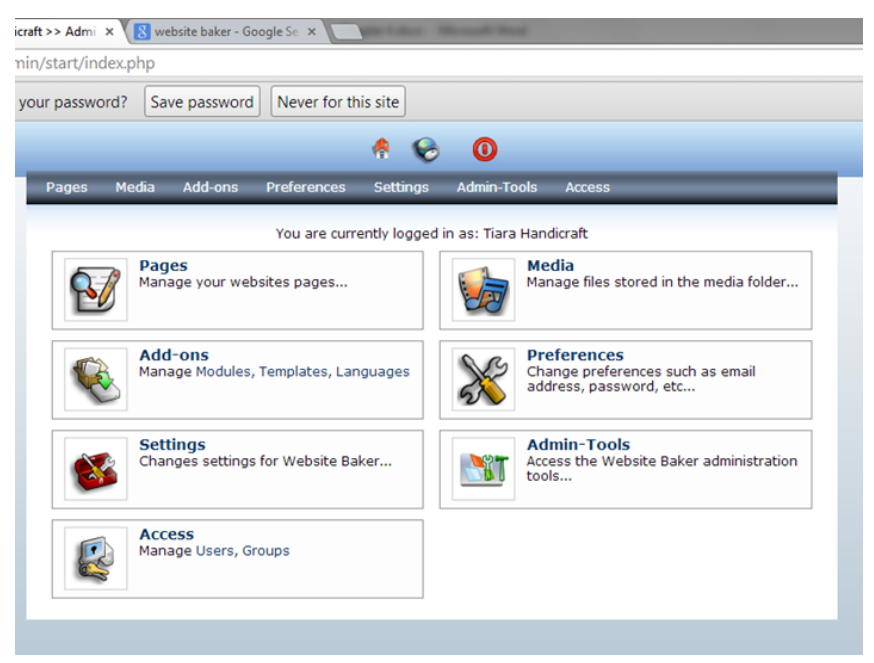

Picture 2: Admin functional tools

Source : www.tiara-handicraft.com

\section{DATA ANALYSIS AND INTERPRETATION \\ Step 1: SWOT Factors}

The external factor that Tiara Handicraft has is a relation with its customer, raw material supplier, partner such as BAPENAS and etc.

\section{Step 2: SWOT Analysis}

From the description above, the strength, weaknesses, threat, and opportunity analyses were described in the table below. This table is written based on the observation process, interview involved employee and also the owner.

\section{Table 1 SWOT Analysis}

\begin{tabular}{|c|c|}
\hline $\begin{array}{l}\text { Strengths } \\
\text { 1. High order } \\
\text { 2. Qualify member to handle } \\
\text { production } \\
\text { 3. Qualified member to handle } \\
\text { IS } \\
\text { 4. Strong business development }\end{array}$ & $\begin{array}{l}\text { Weaknesses } \\
\text { 1. Insufficient time for IS } \\
\text { maintenance } \\
\text { 2. Existing website only } \\
\text { provide one direction } \\
\text { communication } \\
\text { 3. Expensive maintenance of } \\
\text { existing websites } \\
\text { 4. The less understanding in IS } \\
\text { development }\end{array}$ \\
\hline $\begin{array}{l}\text { Opportunity } \\
\text { 1. Interconnected network } \\
\text { 2. Cheaper solution is by using } \\
\text { Prestashop as ecommerce } \\
\text { software } \\
\text { 3. Self-management for future } \\
\text { ecommerce software }\end{array}$ & $\begin{array}{l}\text { Threat } \\
\text { 1. Potential similarities IS with } \\
\text { other SME's that use } \\
\text { prestashop } \\
\text { 2. Lack of maintenance } \\
\text { 3. Very competitive industry } \\
\text { 4. Hosting system down }\end{array}$ \\
\hline
\end{tabular}

Source: Data processed

\section{Step 3: IS Diffusion Strategy}

According to Stewart (2006:689), the predictors for the IS benefit constraint is (1) relevance to the organization (2) project environment (3) user utility. The list of these predictors in case of this implementation is as follows:

1) Reduce the semi manual communication media such as email, SMS, mail and phone call that not being integrated in the system.
2) Several employees will have an access to the Prestashop that will be categorized in the administration panel. In which those employee that involved in the sales procedure.

3) Customer satisfaction will increase due to fast response of the sales system information and also the fast response from the company employees.

In order to achieve the expected and planned benefit above, the system must consist of the asset and process that will affected by the system (stewart, 2006:684). The Asset and also the processes that will be affected by the implementation of the new sales information system are:

1) Improved service activity related to online sales services by using integrated network

2) Reduced the paper-based database

3) The marketing department will take fully control of the online sales activity followed by involved department such as shipping.

4) The sales activity would be reported daily and processed on the same day after the production has been finished.

\section{Step 4: Operational Strategy}

This operational strategy is aimed to make a clear step in operating and handle the initial implementation. In the figure 9 below, it is understood that the preliminary step to handle the implementation strategy:

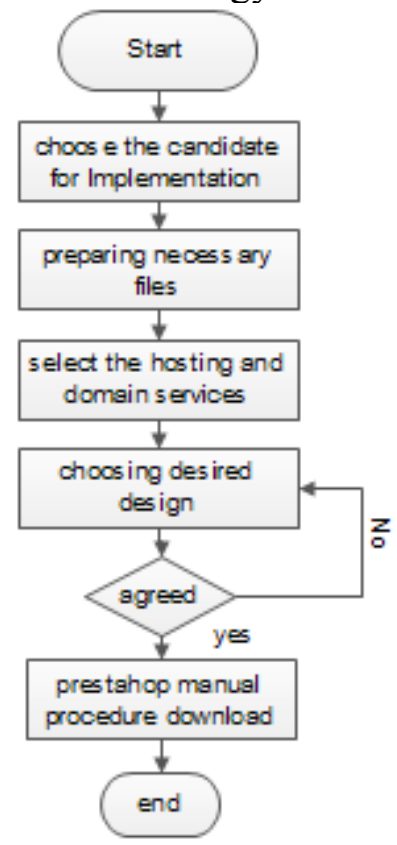

Figure 6: Operational Strategy for proposed Prestashop Implementation

Source : Data Processed

In operating the new system there are several infrastructure requirements in order to support the 
system. The infrastructure is including the computer set, internet connection, and also a digital camera. The minimum infrastructure requirements are set in the lower requirement.

Table 2 Infrastructure Minimum

\section{Requirements}

\begin{tabular}{|l|l|l|}
\hline No. & Necessary Infrastructure & \multicolumn{1}{c|}{ Description } \\
\hline 1. & Computer & $\begin{array}{l}\text { 1 Ghz Intel Processor } \\
\text { 1 GB RAM Memory } \\
\text { 64 MB Graphic Card } \\
\text { 1 GB free space on Harddrive (the space } \\
\text { may vary depend on the file) } \\
\text { LCD Monitor } \\
\text { Keyboard and Mouse }\end{array}$ \\
\hline 2. & Internet Connection & $\begin{array}{l}\text { ADSL Modem 350/Kbps or Broadband } \\
\text { Modem 100/Kbps }\end{array}$ \\
\hline 3. & Digital Camera & $\begin{array}{l}\text { Pocket camera with more than 12 Mega } \\
\text { Pixel sensor for better picture quality }\end{array}$ \\
\hline
\end{tabular}

\section{Source: Data processed}

This operational strategy is started by choosing the employee from TIARA handicraft that will be a candidate to help the researcher in implementing the strategies.

The next step is by preparing the necessary files and application such as the virtual host software, the prestashop files, and also the other necessary files.

After the necessary files have been chosen, it is the time to choose the hosting provider. After the hosting provider has been chosen the next step is choosing the design desired for prestashop. When the design is agreed then it is finished to be continuing to the implementation stage.

\section{Step 5: Implementation Strategy}

In this step the involved employee that would operate the system, will directly handle the system, start from the installation until prestashop backoffice integration in which, every single features of ecommerce software (online shop) would be managed. In implementing for the initial step.

\section{Table 3 Action plan for prestashop}

\section{installation}

\begin{tabular}{|c|c|}
\hline 1. & $\begin{array}{l}\text { Installation of the prestashop web based software } \\
-\quad \text { System requirements } \\
-\quad \text { Hosting integration } \\
-\quad \text { Back office initial used }\end{array}$ \\
\hline 2. & $\begin{array}{l}\text { Time dimension } \\
\text { - } \quad \text { This activity is including in the site establishment } \\
\text { - } \quad \text { This project would be done in two weeks (14) }\end{array}$ \\
\hline 3. & $\begin{array}{l}\text { Cost dimension } \\
-\quad \text { Prestashop software is free ecommerce software. } \\
\text { - The cost that for this project is only to pay the hosting } \\
\text { that also covers the domain. }\end{array}$ \\
\hline 4. & $\begin{array}{l}\text { Human resource dimension } \\
\text { - There will an involvement of the capable employee to } \\
\text { works from start to finish of this project. }\end{array}$ \\
\hline
\end{tabular}

Source: Data processed

In operating the Prestashop as ecommerce software, it is necessary to understand several steps in implementing this system. Basically there will three basic steps in implementing the system as stated on the table 7 which is in the installation procedure, there will consist of system requirements, hosting integration, and also the initial back office setup.

\section{Table 4 Minimum system requirements}

\begin{tabular}{|c|c|}
\hline & To \\
\hline $\begin{array}{l}\text { d operating system: } \\
\text { Mac and Linux } \\
\text { ed package: Wamp (for } \\
\text { or Xampp (for } \\
\text { and Mac) } \\
\text { ver: Apache 1.3, Apache } \\
\text { x or Microsoft IIS } \\
\text { installed and enabled } \\
5.0+\text { installed with a } \\
\text { created }\end{array}$ & $\begin{array}{l}\text { a. A domain name } \\
\text { b. Web server: Apache 1.3, } \\
\text { Apache 2.x, Nginx or } \\
\text { Microsoft IIS } \\
\text { c. PHP 5.1+ installed and } \\
\text { enabled } \\
\text { d. MySQL 5.0+ installed with a } \\
\text { database created } \\
\text { e. FTP access (ask for your } \\
\text { credentials) }\end{array}$ \\
\hline
\end{tabular}

Source: www.prestashop.com

From the system requirements above, it is understood that the further implementation steps are as follows:

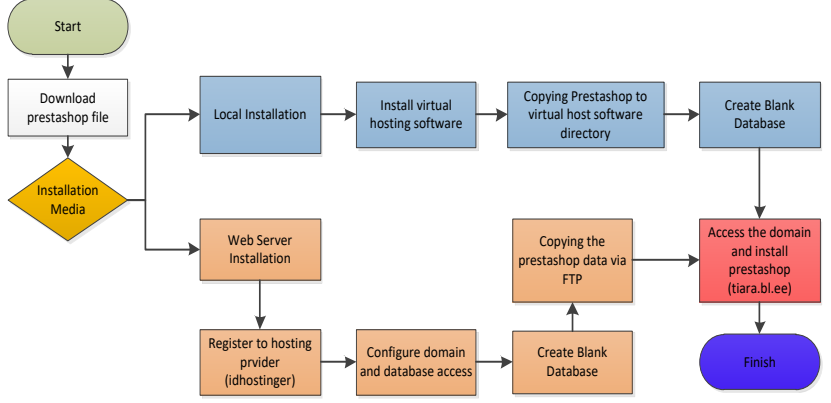

Figure 7 : Detailed Installation procedures Source : Data processed

In the detailed procedure, basically there will two options to install the prestashop on as shown on figure 7. There will installing on host computer and also installing on the web server. The system interface and the installation would be almost the same between them.

\section{Back-Office}

After the installation has been done, the first page will be the front office, but for the admin panel is in the back office. The back office page can be accessed through adding the specific folder of the administrator page where the admin files saved (https:/tiara.bl.ee/admineka). The initial used of the back office is really matter to understand the function of the back office which is consist of following function such as "Catalog", "Sales", "Customer", "Price Rule", "Shipping", "Localization", "Module", "Preferences", "Advanced Parameters", "administration", and also the "Statistic" function as shown on the picture 4.

\section{Front-Office}


The other part of prestashop that take the larger attention is the front office in tiara.bl.ee in which this web page is similar with the showroom in physical store. This front office is used to interact with the potential customer. Basically there will 4 building blocks of the navigation panel in this front office. It consist of, Login navigation bar, product navigation bar, main navigation bar, and the featured product showcase.

This websites front-office is customizable through the back-office page. The navigation page itself is constructed from modules that's why it will looks like building block that can be change whenever the administrator want to change the part.

\section{Sales Procedure by using prestashop}

In the implementation stage of prestashop, the sales procedure involved in the previous system, would be rearrange following the prestashop sales procedure. The sales procedure would be shown in the figure 8 below:

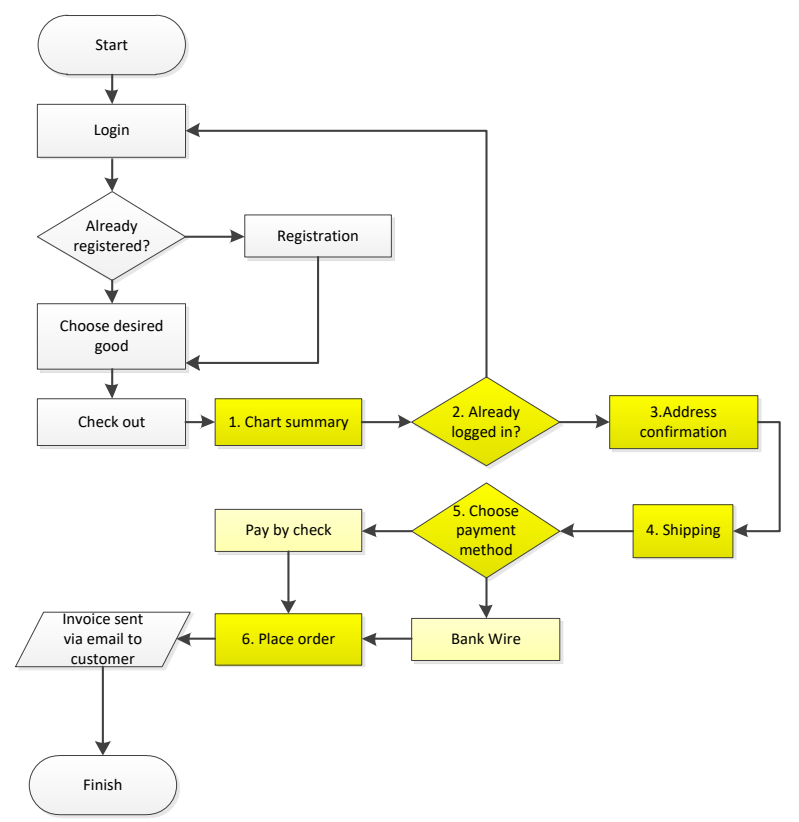

Figure 8: Sales procedure by using prestashop Source : Data processed

After the sales (purchase) method has been done, the payment method can be done through semi manual procedure adjusting to the prestashop data as follows:

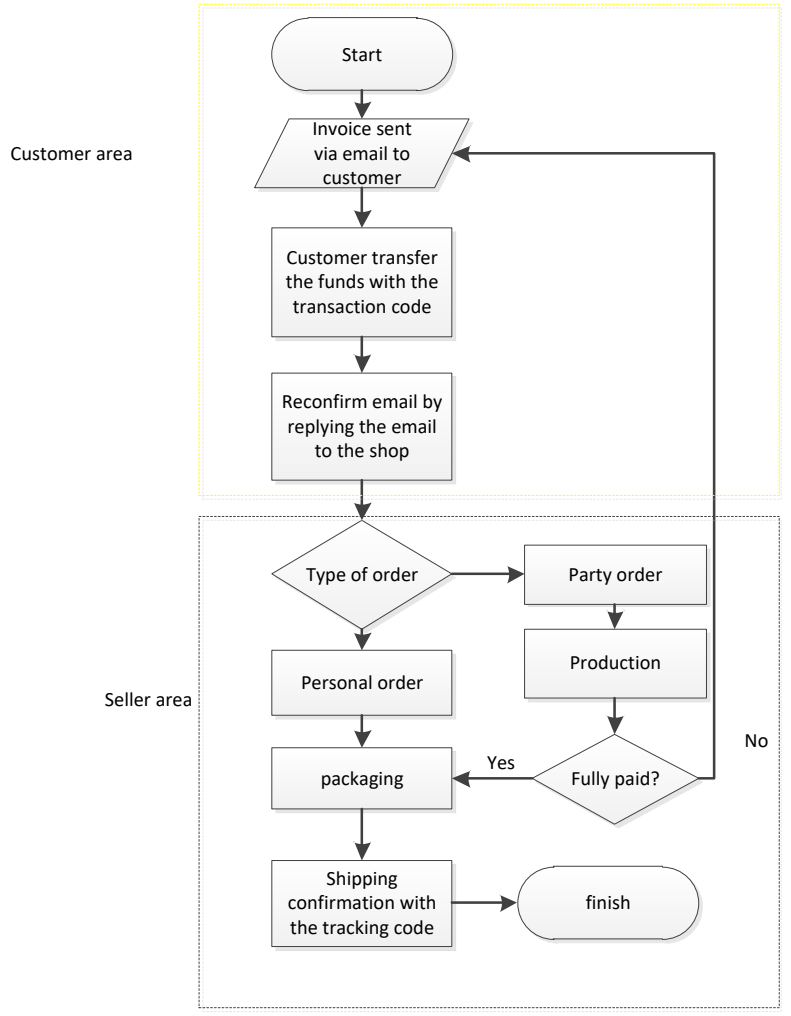

Figure 9: Payment and shipping procedure

Source : Data processed

\section{Step 6: Monitoring Plans}

When the system is already implemented, the further step is by analyzing the system usefulness from the end users and also the administrator in which they are involved in this system implementation strategies. In monitor the system performance it can be seen from the statistical data that recorded into the back office feature in the "stats menu".

\section{PROPOSITION}

Proposition of this research is stated as follows:

1. If the prestashop as an ecommerce software is being implemented at Tiara Handicraft, it will give the more useful features in ecommerce rather than that the existing one that only contain the product information.

2. If the prestashop as an instant ecommerce software were be implemented at Tiara Handicraft it will reduce the time duration and also built cost of system implementation rather than using the customized software that built by web-developer based on order.

3. If prestashop is being implemented at Tiara Handicraft, it will create an effective sales process, especially at the online sales to widen the market reach. 
4. If prestashop is implemented at Tiara Handicraft, the system security would be the more secured rather than that the customized one since it has been used by so many SME's around the world.

\section{Closing}

\section{A. Conclusion}

According to the research conducted at Tiara Handicraft, Surabaya, related with strategic implementation of automated online sales information systems for small and medium enterprise's (SME'S), it is concluded that:

1. Ecommerce networking is a right solution for SME's to move their market and also broaden the market area to move overseas.

2. The competition todays are heating not only for the large enterprise but also for the SME's.

3. In todays IS product, establishing the information system is no longer related with the cost dimension issues in which it may great barriers for the SME's to use the ecommerce.

4. By using the free software like prestashop it will give the more benefit rather than using the fully customized one that built by web developers or by using the free Content Management System (CMS) in which this kind of IS product only provide several function for ecommerce function.

5. Using prestashop is a whole solution for a low budget SME's that want to have an ecommerce as sales information system since this allow the SME's as user to manage the sites from start to finish of the system implementation.

6. The opportunity created by implementing the free ecommerce application will give a large impact to Tiara to broaden the market area especially in Indonesia

\section{B. Suggestion}

1. In order to maintain the competition especially to reach the outer space of market, implementing the ecommerce software is an alternative that cost effective and efficient.

2. For the next researcher, it is important to find and solve the problem related with the payment procedure.

3. The next researcher may able to increase the system stability and the security level.

4. By using prestasop as ecommerce instant software, the cost of operational can be minimized since the program is not a custom built.

5. By using Prestashop it is expected that the user can draw the sales valuation and evaluation directly from the statistical features included in prestashop.

6. It is expected that from the recent system implementation that are able to support the ecommerce operation.

\section{References}

Ang \& Iriana. 2006. Sales force automation:

review, critique, research agenda.

International Journal of Management

Reviews: 213-231

Astalin, Phrasant K. 2013. Qualitative Research

Designs: A Conceptual Framework.

International Journal of Social Science \&

Interdisciplinary Research: 118-124

Creswell, John W. 2007. Qualitative Inquiry \&

Research Design. California: Sage

Publication

Kotelnikov, Vadim. 2007. Small and Medium Enterprises and ICT. Thailand: Keen Media (Thailand) Co., Ltd

Levi, Margie and Powell, Philip. 2005. Strategies for Growth in SME's. Burlington: Elsevier Limited

Miller, John. 2013. The Definitive Guide To Marketing Automation. San Mateo: Marketo

Oz, Effi. 2009. Management Information System Sixth Edition. Massachutes: Cencage Learning, Inc.

Partomo, Tiktik. 2004. Usaha Kecil Menengah Dan Koperasi. Center for Industry and SME's Studies Faculty of Economics University of Trisakti

Stewart, et.al. 2002. Strategic implementation of IT/IS projects in construction: a case study. Automation in Construction $11681-694$. Australia: Elsevier

\section{Online}

Wisegeek. 2013. What Is Automated Sales?. [Online] (http://www.wisegeek.com/whatis-automated-sales.htm, 29/01/201308.01 WIB)

Tempo news. 2013. UKM Dorong Pertumbuhan Ekonomi Tembus 6,3 Persen, [online] http://www.tempo.co/read/news/2013/07/03 /092493157/UKM-Dorong-Pertumbuhan- 
Ekonomi-Tembus-63-Persen,

accessed

11/11/2013 10.36 WIB) 